whose arrival the introduction of the pestilence into that island has been confidently ascribed, went on there as their point of destination. At Benghazi, too, intermediate between Alexandria and Tunis, many of the fugitive pilgrims went, and it is believed that not a few of them died there soon after reaching the place. Whatever may be the truth on this point-for unfortunately no precise information about it has ever been published,-it is certain that the disease did not extend to the inhabitants. The same seems to have been the case in respect of Algeria. Cases of cholera were repeatedly imported in 1865 by French Government steamers, and other vessels, from Marseilles, where the disease was so prevalent during the summer and autumn; but it never took root or became diffused among either the military or civil population.

Throughout 1866, the year when the continent of Europe was most widely and severely infected, there was little, if any (as far as I am aware), cholera in Africa. Egypt was nearly, if not altogether, exempt, and the Mecca pilgrimage passed over with extremely little sickness among the multitudes gathered together, as well during the assemblage as during the subsequent dispersion. Tunis still remained free, and Malta that year had no return of the malady. It was not till the spring of 1867 that it made its appearance in Tunis; whence or how it then came was wholly unknown. It spread from the town of that name along the coast to Susa in a south-easterly direction, and also, it was said, into the interior of the country. About the same time that the Tunisian states were suffering Algeria seems to have been more decidedly affected than it had hitherto been; and in August Malta, after an immunity of eighteen months, again became the seat of an outbreak, from which both the garrison and the civilians suffered considerably.

The part of the north African coast to the westward of Algeria appears to have continued unaffected till towards the end of this year, for the earliest public notice of the disease being in Tetuan, Ceuta, or Tangiers, was, I believe, in January, 1868. These places had entirely escaped in 1865, during the prevalence of the epidemic in Gibraltar (immediately opposite to Ceuta) and in the south of Spain, between which and this part of the Barbary coast there is a great amount of intercourse.

In the spring or early summer of 1868, the disease had reached to various points on the Atlantic coast of Morocco, to the south of Tangiers, and between the 35th and 33rd parallels of latitude, as at Larache, Casalblanca, Mazagan, and Saffi. Later in the season we heard of its being at Mogadore, still further to the south. Whether the disease had altogether ceased, as was reported, throughout the Moroceo states in the latter part of the year, when St. Louis, the capital of the French possessions in Senegal, and in latitude $16^{\circ}$, was invaded, it is impossible to say. The intermediate country is very sparsely inhabited, and there is no place of any consequence on that part of the coast. The disease is believed to have spread inland from St. Louis along the course of the Seneoal river; but we have no exact intelligence to enable us to follow its track.

In March, in the present year, it was raging in the British settlement of Macarthy's Island, nearly due east of the French possessions, and it was also moving more southerly along the coast in the direction of our colony of Bathurst, in latitude $13^{\circ}$, near the mouth of the river Gambia, where it appeared in May, and afterwards proved so disastrously fatal among the coloured population. This is the most southerly point which the pestilence has, as yet, reached along this part of the African coast. Whether and when it will extend further in this direction, and arrive at our im. portant settlement of Sierra Leone, between five and six degrees nearer the equator, remains to be seen.

The preceding data serve, mean while, to show that in this part of the world the march of the pestilence during the last two years has been slow and progressive along an extended line of country. Similar events, it is well known, have been observed in other regions on former epidemics. Do not they seem to suggest, among other considerations, that there must surely be ather factors or influences in the diffusion of cholera besides that of mere personal intercom munication? and that, unless the former are present at the same time, the latter agency is insufficient in itself to account for its extension from one place to another?

The only other point to which I would invite attention at present is, that in 1856, when there was a widespread dif- fusion of the pestilence along the coasts of Barbary and of Morocco, several of the islands in the Madeira and the Cape de Verde groups, suffered for the first time from a visitation of cholera. Madeira is in about the same latitude as Mogadore, and the Cape de Verdes in about that of Senegal. It would be a matter of no small interest to know whethes there has been any unusual prevalence of choleraic or other intestinal disorders, during the present or last year, in any of these or of the intermediate Canary groups of islands. Possibly some reader of THe Lancer may be able to give the profession information on this point. The obtaining of trustworthy data about the synchronous health-state of different regions, especially of adjacent or contiguous countries, is one of the most important elements in the elucidation of the natural history, and particularly of the migratory course, of epidemic diseases.

I am, Sir, your obedient servant,

Richmond, S.W., Oct. 1869. Gavin Mruroy, M.D.

\section{AN UNUSUAL CASE OF VACCINATION.}

\section{To the Editor of THE LANCET.}

Sir,-The following case is one of such unusual occurrence that I venture to ask you to give it a place in your columns.

Three months ago my partner vaccinated a child two years of age on the left arm, which failed to take effect. At the end of last month I vaccinated a younger member of the same family, and from this child on the seventh day I vaccinated the child previously vaccinated by my partner, bnt on the right arm. On the seventh day the child was brought to me, having three fine vesicles on the right arm and one on the left. I thought I must have vaccinated the child on both arms, but the nurse distinctly states that I did not touch the left arm, and of this I have a perfect recollection. The vesicle on the left arm was perfect, and in every respect resembled those on the right arm.

Two questions arise from this case. Has the vaccine used by my partner three months since lain dormant, and was it aroused into activity by the recent vaccination? Or can vesicles be produced on other parts of the body as the result of the introduction of vaccine virus into the system, in the same way as the virus from small-pox?

I am, Sir, your obedient servant, JOSEPH MoRRIs, M.D., M.R.C.S.

Poplar House, Barnsley, Aug. 1th, 1869.

\section{NEWCASTLE-ON-TYNE.}

(FROM OUR OWN CORRESPONDENT.)

Twe Northumberland and Durham Medical Society held its annual meeting at our Infirmary library on the 30th ult. On this occasion this flourishing and highly useful Society attained its majurity. Only two or three of its original members were present, and, although the career of the Society must have fulfilled their most sanguine expectations, to them the retrospect could not fail to have a tinge of sorrow, remembering the absence of so many of the familiar faces of those who aided in the establishment of the Society twenty-one years ago, as the "Newcastle and Gateshead Pathological Society." At the meeting on the 30th ult. a proposition was brought forward by Dr. Eastwood, of Darlington, for the extinction of the Society as a separate body, by its union with the Northern Branch of the British Medical Association. Dr. Eastwood's important recommendation gave rise, as might be expected, to a long and rather animated discussion, and a good deal was said by various speakers for and against the proposed amalgamation; but the feeling of the meeting appeared to be against the union, at least in the mauner suggested by Dr. Eastwood. The President (Dr. Gibson) could not see that the Society could derive any advantage from the union; on the contrary, he thought it night possibly forfeit many of its present highly prized features. Dr. Philipson and some other members thought that the advantages of union as regards both Societies were pretty fairly balanced; and, while carefully abstaining from any decided opinion on the matter in its 